\title{
ISOLATION AND ENZYMATIC FRAGMENTATION OF GENOMIC DNA FROM UNCULTURED MICROBIAL SYMBIONTS OF Theonella sp. SPONGE AS PREREQUISITE FOR METAGENOMIC LIBRARY CONSTRUCTION
}

\author{
Agustinus Robert Uria ${ }^{1)}$, Ifah Munifah ${ }^{1)}$, and Ekowati Chasanah ${ }^{1)}$ \\ 1) Research Center for Marine and Fisheries Product Processing and Biotechnology
}

Received April 4-2007; Received in revised form August 9-2007; Accepted September 7-2007

\begin{abstract}
Microbial symbionts of sponges are well known as the sources of numerous bioactive products which are of potential industrial and pharmaceutical importance, including secondary metabolites, enzymes, lipids and heteropolysaccharides. The general inability to cultivate the majority of symbionts has hampered attempts to access their diversity and restricted exploitation of their bioactive products. However, using a recently developed, holistic molecular approach called metagenomics, the bioactive products can be accessed in a sustainable way. This approach involves construction and screening of metagenomic libraries for finding the genes of interest from uncultured symbionts, followed by transferring the genes into easily cultivated microbes, thereby producing the encoded bioactive compounds in significant amount. We report here three preliminary steps required for the shotgun based construction of metagenomic library from symbionts of a sponge 1) preparation of uncultured microbial cells from a sponge sample; 2 ) isolation of microbial metagenomic DNA; and 3) generation of large DNA fragments of 4 to $10 \mathrm{~kb}$. These resulting large fragments are ready to be cloned into a bacterial host for generating a complex metagenomic library.
\end{abstract}

KEYWORDS: microbial symbionts of marine sponge, genomic DNA isolation, ezymatically DNA fragmentation

\section{INTRODUCTION}

Among marine invertebrates, sponges (porifera) remain the most profilic phylum, concerning novel biologically active natural products (Thakur \& Muller, 2004). Marine bioactive products derived from sponge may include secondary metabolites, enzymes, lipids, and heteropolysaccharides (Gudbjarnason, 1999). There are growing evidences that numerous natural products originally isolated from sponges have been subsequently discovered to be localized in microbial symbionts (Faulkner, 2000; Piel et al., 2004). For instance the two group of metabolites, polyketides, and nonribosomal peptides, isolated from sponges revealed a highly similarity to those exclusively known from microorganisms (Piel et al., 2004). In particular, (Bewley et al., 1996) demonstrated that cyanobacterial cells separated from cells of the sponge Theonella swinhoei produced the cytotoxic macrolide Swinholide A and many bioactive cyclic peptides. Similar evidence was also reported by (Schmidt et al., 2000) indicating that the filamentous bacterial symbionts of $T$. swinhoei were the producers of the antifungal theopalauamide.

Exploration of bioactive products from these symbiotic microorganisms is usualy carried out by isolation and cultivation of symbionts, followed by optimization of production in bioreactor. However, this cultivation dependent way is hampered by the general difficulty in cultivating the majority (over 99\%) of microbial symbionts, subsequently reducing the chances of gaining access to many promising natural products. Although efforts to increase the number of symbionts in pure cultures have been made by developing new culture media based on a better understanding the nutritional requirements for bacterial growth, access to the majority of microbial diversity still remains difficult (Bertrand et al., 2005).

Recent advances in biotechnology, marked with the birth of metagenomics, has opened up the exciting possibility to produce natural products of uncultured microbial origin in easily cultured bacteria. This holistic cultivation independent approach are based on the ability to transfer the genetic material from uncultured bacteria to an cultured laboratory bacterium such as Escherichia coli. In principle this approach may involves 1) construction and screening of metagenomic library from uncultured symbiotic microbes for finding the genes responsible for manufacturing desired natural products; and 2) subsequent transfer and over expression of the genes into easily culturable microbes, thereby producing target products in significant amount (Uria et al., 2006). In particular, construction of metagenomic library from microbial symbionts of a sponge may consists of 1 ) preparation of microbial cells without cultivation; 2) isolation of intact metagenomic DNAs from uncultured microorganisms and generation of relatively large DNA fragments either by partial digestion or polymerase chain

Corresponding author: 
reaction (PCR); and 3) cloning of DNA fragments into a bacterial host, ussually Escherichia coli, to generate a DNA library.

In our preliminary work on metagenomics, we report our results on extraction and purification of intact genomic DNA from uncultured symbionts of marine sponge. The purified metagenomic DNA could be useful as the template for isolating gene clusters encoding biosynthetic pathways for secondary metabolites. In addition, we report here on generation of relatively large DNA fragments in the size range of 4 to $10 \mathrm{~kb}$ through partially enzymatic digestion. The resulting DNA fragments is prerequisite for shotgun construction of metagenomic libraries harboring single biocatalyst encoding genes.

\section{MATERIALS AND METHODS}

\section{Collection of Sponge Sample and Isolation of Uncultured Symbionts}

Asponge sample was collected in Kodek Bay, Lombok Island, Indonesia on June 2006. Sample collection was carried out by scuba diving at the depth of around $10 \mathrm{~m}$. The sample was stored in a cool box and transported to the laboratory in Jakarta for molecular analysis. Uncultured symbionts of the sponge sample were prepared based on the procedure modified from (Bewley et al., 1996). Sponge sample (100 g) was homogenized in $200 \mathrm{ml}$ of sterile sea water, and then centrifuged at $100 \times \mathrm{g}$ for $10 \mathrm{~min}$. The supernatant was passed through a 40-ìm nylon membrane (Millipore), and the filtrate was centrifuced at $200 \times \mathrm{g}$ for $5 \mathrm{~min}$. The resulting bacterial cell pellet was rinsed three times by using sterile sea water, and then stored in a storage TE buffer $(0.05 \mathrm{M}$ Tris- $\mathrm{Cl} \mathrm{pH} 8.0 ; 0.1 \mathrm{M}$ EDTA) at $-20^{\circ} \mathrm{C}$. The number of uncultured microbial cells in a defined volume of TE buffer was estimated using a hemacytometer under an inverted microscopy (Olympus TH4-200) at a 400-x magnification.

\section{Extraction and Purification of Metagenomic DNA}

The pure intact genomic DNA from uncultured microbial cells was prepared by these sequential steps cell lysis and protein denaturation, protein removal and DNA recovery, DNA purification and quantitation. The detailed procedure for cell lysis and protein denaturation from a small scale cell preparation was performed on the basis of the procedure modified from (Bertrand et al., 2005). Uncultured cell pellet was suspended in $1.5 \mathrm{ml}$ TE buffer (10 mM Tris-Cl pH 8.0, 100 mM EDTA) and then frozen at $-20^{\circ} \mathrm{C}$ for $30 \mathrm{~min}$. The frozen cell suspension was added with 150 ì of $10 \mathrm{mg}$ per ml lysozim, melted at room temperature, and then placed soon on dry ice for 1 hour.
To breakdown the cell wall of positive gram microbes, 50 il of $20 \mathrm{mg}$ per $\mathrm{ml}$ achromopeptidase was added into the cell suspension and incubated at $37^{\circ} \mathrm{C}$ for 1 hour. Subsequently the protein present in the suspension was hydrolyzed by adding $1 \mathrm{ml}$ of proteinase $\mathrm{K}$ solution (1 $\mathrm{mg}$ per $\mathrm{ml}$ in $1 \% \mathrm{~N}$-lauryl sarcosine, $50 \mathrm{mM}$ Tris- $\mathrm{Cl} \mathrm{pH}$ 8.0, 0.4 M EDTA), followed by an 1 hour incubation at $60^{\circ} \mathrm{C}$. The hydrolysed proteins present in the DNA solution was removed by extracting first with phenol:chloroform $(1: 1)$ and then with choloroform (Sambrook \& Russel, 2001). Subsequently, the DNAs were recovered from aqueous solution by precipitation with ethanol (Sambrook \& Russel, 2001). The DNA solution was added with 0.1 volumes of $3 \mathrm{M}$ sodium acetate at $\mathrm{pH}$ 5.2. After being mixed, the solution was added with 2 volumes of cold absolute ethanol, and mixed well. The DNA precipitate was obtained by centrifugation at $14.000 \mathrm{rpm}$ for 20 minutes, followed by careful removal of the supernatant. The tube was filled half way with $70 \%$ ethanol and then centrifuged at $14.000 \mathrm{rpm}$ for 20 minutes in microfuge tubes. The remained fluid traces were evaporated at $45^{\circ} \mathrm{C}$ for 3 minutes in a thermoblock. The formed DNA pellet was dissolved with 50 ì of a TE buffer $(50 \mathrm{~m} \mathrm{M}$ Tris-Cl $\mathrm{pH} 7.6$ and $1 \mathrm{~m} \mathrm{M}$ EDTA) and the RNA was removed by adding DNase free RNase (Roche). The DNA obtained was purified by using Wizard ${ }^{\circledR}$ DNA Clean up System (Promega) according to the manufacturer's recommendations. Amount of the purified DNA was measured at $260 \mathrm{~nm}$ using an UV spectrophotometer (Hitachi), and the DNA purity was estimated by the ratio between readings at 260 and $280 \mathrm{~nm}$. The pure intact DNA obtained was electrophorectically run on $0.6 \%$ low melting temperature agarose gel with the support gel of $1 \%$ standard agarose. The presence of the DNA was visualized on a UV transluminator and documented using a Gel Doc apparatus (Biometra).

\section{Partial Digestion of Metagenomic DNA}

Pure metagenomic DNA (0.05 ìg/ì) was partially digested by using Sau3A1 at various different concentrations. Around 250 il of the pure DNA was distributed into seven eppendorf tubes, in which volume of tube 1 was 60 il and others were 30 il each. All of the tubes containing DNA solution were placed on dry ice. Tube 1 was filled with 8 units of Sau3A1 and mixed well. Half volume of the mixture (30 il) was taken out and added into the tube 2. After being mixed, 30 il of the mixture in tube 2 was transferred to tube 3 , and so on up to tube 6 . The tube 7 was not added with enzyme solution and used as the control. Subsequently, the seven tubes were incubated at $37^{\circ} \mathrm{C}$ for 1 hour on a thermoblock (Biometra). The digestion reaction was terminated by subsequent heating the tubes at $70^{\circ} \mathrm{C}$ for 15 minutes, followed by adding 6-x loading dye buffer. The digested 
products were electrophoretically separated on $0.7 \%$ low melting temperature agarose gel. The resulting DNA bands were visualized and documented using a Gel Doc apparatus (Biometra). The size of DNA bands was determined on the gel by their comparison with DNA molecular weight marker IV (ë DNA and pSPTBM 20 DNA digested with Sty I and Sau I) (Roche). Fragments in the size range of 4 to $10 \mathrm{~kb}$ in the gel was sliced using a sharp blade and then extracted by using QIAquick Gel Extraction Kit (Qiagen) according to the manufacturer's instructions.

\section{RESULTS AND DISCUSSION}

Construction of marine metagenomic libraries containing clones with relatively large DNA inserts requires developing methods for the extraction and purification of intact or undegraded genomic DNA from symbiotic microorganisms. Methods for metagenomic DNA extraction in principle can be classified into direct and indirect approaches. The direct approach is based on extraction of total DNA directly from a whole sponge sample. Whereas indirect approach is initiated with isolation of uncultured microbial cells from a sponge sample, followed with extraction of DNA from the obtained microbial cells. Such cell isolation has been demonstrated for the sponge Theonella swinhoei using a differential centrifugation as reported by (Bewley et al., 1996). Three distinct bacterial cell populations were successfully separated from sponge cells. They consisted of unicellular heterotrophic bacteria, unicellular cyanobacteria and filamentous heterotrophic bacteria. In particular, the filamentous symbionts have a distinct morphology and can be clearly recognized under a light microscopy (Bewley et al., 1996; Schmidt et al., 2000).

In our metagenomic work, we considered to employ indirect approach for DNA isolation. The main consideration of choosing this approach is that the DNA obtained is mostly originated from bacterial symbionts and relatively undamaged. Of special interest for the symbiont source was the sponge Theonella, which grows around Lombok (Figure 1a). The microbial cells isolated from this sponge were observed under an inverted microscopy at a 400- $x$ magnification. The results (Figure $1 b)$ indicate the presence of bacterial cell population with a small portion of filamentous heterotrophic bacteria as indicated with an arrow. The cell density in such cell preparation was estimated to be $2.3 \times 10^{8}$ cells per $\mathrm{ml}$ using a hemacytometer.
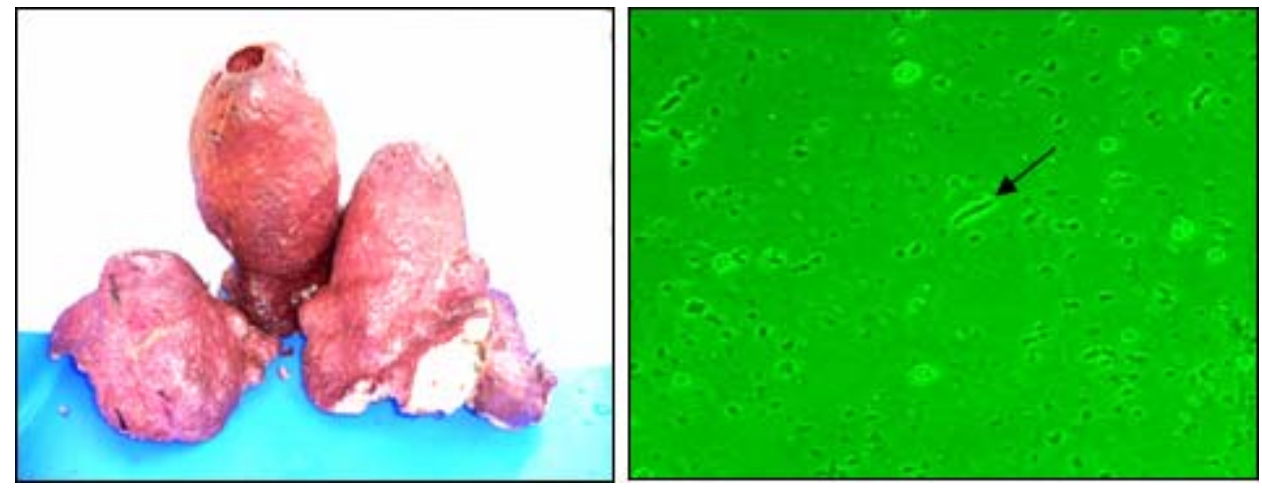

Figure 1. Isolation of microbial symbionts of marine sponge. (a) A sponge sample, predicted as the genus Theonella, collected from Lombok Island. (b) Uncultured bacterial cells isolated from the sponge which was observed under an inverted microscope at $400 \times$ magnification. Filamentous heterothropic bacteria was marked with an arrow.

The genomic DNA from bacterial cells obtained were subsequently prepared in pure form. It was found that the pure DNA concentration obtained was $55 \mathrm{ig} / \mathrm{il}$ and the amount of DNA recovered from $1.5 \mathrm{ml}$ of cell suspension $\left(3 \times 10^{9}\right.$ cells per $\mathrm{ml}$ ) was $2.75 \mathrm{mg}$. The ratio between readings at 260 and $280 \mathrm{~nm}$ was 1.7 which approaches the purity range of DNA (1.8 to 2.0). The genomic DNA obtained was then checked by a standard electrophoresis (Owl B1A) through a $0.7 \%$ LMP agarose. The result, as shown in Figure 2, revealed the presence of the genomic DNA which was located on the higher part of the gel, suggesting that the DNA existed in very large sizes. A small amount of the DNA still remained on the gel wells because the DNA size was very large and the gel pores were small enough for the DNA to pass through. The DNA smear was almost undectable at the lower part of the gel confirmed that the genomic DNA existed in relatively large sizes. However it is difficult to estimate the exact size of the genomic DNA, since the genomic DNA location was above the maximal size of the largest marker band. 

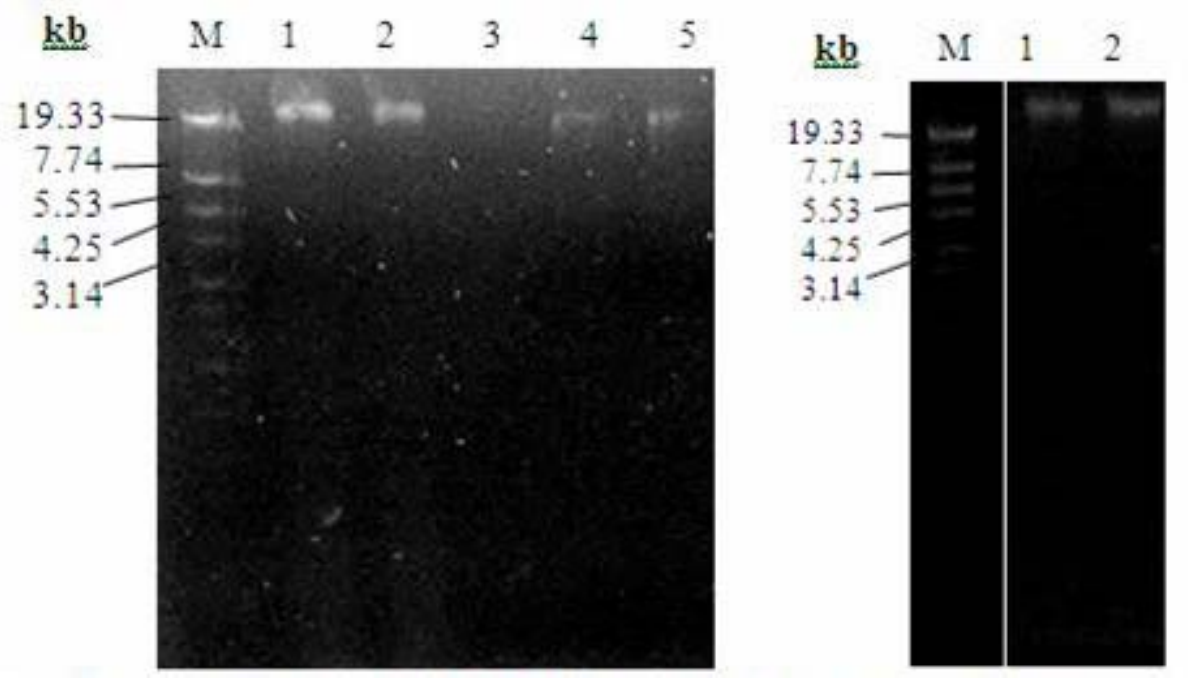

Figure 2. Intact DNA from uncultured microbial symbionts of the marine sponge, Theonella sp. Notes: $M$ is DNA molecular weight marker IV (ë DNA and pSPTBM 20 DNA digested with Sty I and Sau I). Lanes 1 and 2 of the left figure are extracted total DNA from uncultured cells, lanes 4 and 5 are total DNA from cultured cells. Lanes 1 and 2 of the right are purified total DNA from uncultured symbionts.

As prerequisite for construction of a metagenomic DNA library, DNA fragments need to be generated from high molecular weight DNA either by partial fragmentation or PCR-based amplification. In particular, a partial fragmentation can be performed in a quasi random fashion by using hydrodynamic shearing. However, the DNA prepared in this physical way requires extensive enzymatic manipulation to protect internal restriction sites and to generate cohesive termini compatible with those of the vectors used to generate DNA libraries (Sambrook \& Russel, 2001). For such reason, we employed an enzymatic based approach for fragmenting the puried HMW DNA in order to produce DNA fragments which can directly be used for metagenomic library construction without further manipulation. Such enzymatic fragmentation was based of the use of a restriction enzyme that recognizes a 4-bp sequence and generates a cohesive terminus. One of the enzymes most widely used for this purpose is Sau3A1 (Sambrook \& Russel, 2001). This enzyme cut the DNA frequently with the recognition site of GATC and the ends of digestion products generated can directly be cloned into a $\mathrm{BamHI}$ site of a vector.

To maximize the yield of DNA fragments for insertion into a vector, the appropriate conditions for such partial digestion were established in small scale reactions. This is aimed at knowing the amount of enzyme needed to yield the DNA fragments of 4 to $10 \mathrm{~kb}$. The result of the small scale digestion was shown in Figure 3a. A smear fragment gradient appeared on the gel from lanes 1 to 6 . Whereas the lane 7 appeared as a single band since the DNA sample loaded was not treated with a restriction enzyme and be used as the control. The successful enzymatic restriction confirmed the high quality (purity) of this DNA sample. In particular, the fragments of 4 to $10 \mathrm{~kb}$ were identified in the lines 5 and 6 (marked with an open pink square). The final concentration of Sau3A1 needed to produce such target size range was found to be 0.010 to $0.016 \mathrm{U} / \mathrm{il}$.

Based on the conditions established for the small scale preparation, a larger scale fragmentation reactions was then set up, in which each containing Sau3A1 in the final concentration range of 0.010 to $0.016 \mathrm{U} / \mathrm{il}$. The results (Figure $3 b$ ) showed the present of fragment smears from lane 1 to 4 . The fragments in each lane seemed to be smear because they were extremely dense and generated from complex genomes of various different microbial species. Whereas the lane 5 revealed a thick DNA band, suggesting that the DNA was undegraded. The resulting target fragments were subsequently sliced using a sharp blade and then extracted by using QIAquick Gel Extraction Kit (QIAGEN). The extracted fragments can be used for constructing a metagenomic library and screening for biocatalyst encoding genes. 

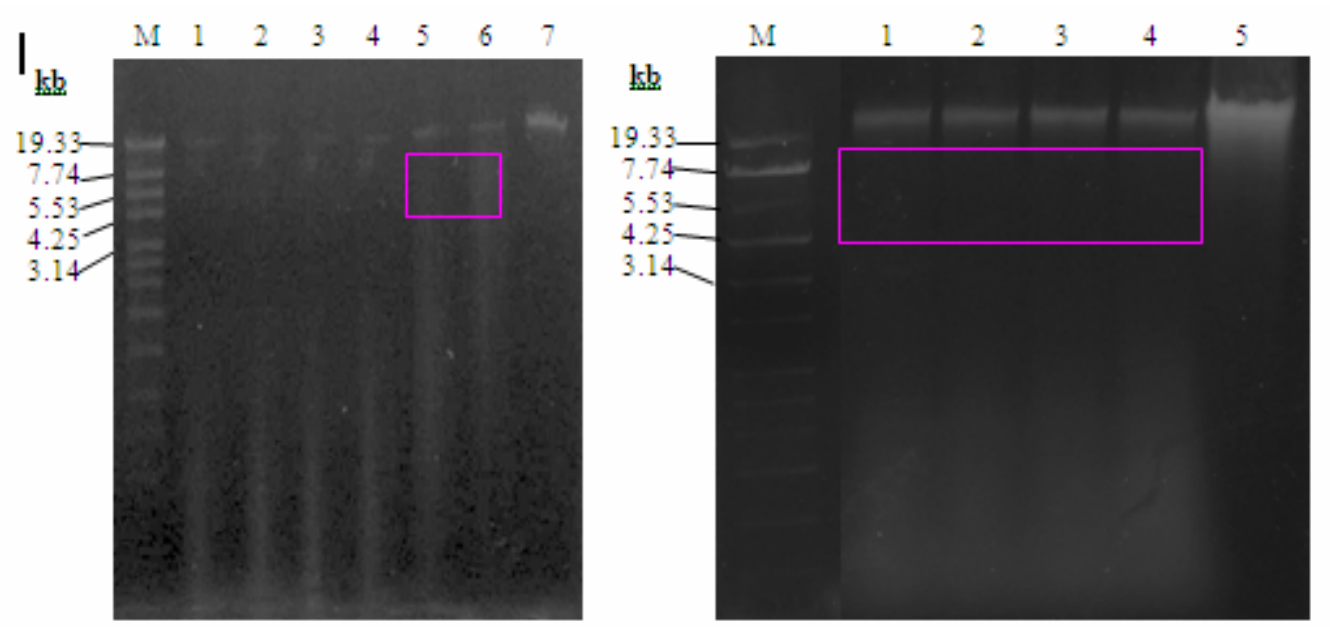

Figure 3. Enzymatic digestion of metagenomic DNA. Notes: $M$ is DNA molecular weight marker IV (ë DNA and pSPTBM 20 DNA digested with Sty I and Sau I), lanes 1 to 6 of the left figure and lanes 1-4 of the right are the purified total DNA digested at different concentrations of Sau3A. Lane 7 of the left and 5 of the right is the undigested and purified total DNA from cultured cells. Fragments marked with a pink open box (in the size range of around 4 to $10 \mathrm{~kb}$ ) were extracted from the gel.

\section{CONCLUSION AND RECOMMENDATION}

Shotgun based construction of a metagenomic library from total sponge DNA requires isolation of metagenomic DNA from sponge symbionts as well as enzymatic fragmentation of HMW DNA. Preparation of symbiotic cells prior to DNA isolation is considered as an efficient way for gaining access to metagenomic DNA since the DNA obtained is mostly originated from bacterial symbionts and relatively undamaged. Isolation of metagenomic DNA involving the use of achromopeptidase gave $2.75 \mathrm{mg}$ of pure DNA from $1.5 \mathrm{ml}$ of cell suspension ( $3 \times 10^{9}$ cells per $\mathrm{ml}$ ) with the DNA concentration of 55 ig per ìl. Optimal conditions for generating DNA fragments of 4 to $10 \mathrm{~kb}$ can be achieved by using Sau3A1 in the final concentration range of 0.010 to $0.016 \mathrm{U}$ per ì for 30 minutes. These large DNA fragments are ready to use for shotgun-based construction of a metagenomic library.

As the follow up of this preliminary research, we are currently working on cloning of such large DNA fragments into $E$. coli for generating a complex metagenomic library. The resulting library will be amplified through a three dimensional cultivation and then be screened for positive clones with desired enzymatic activities by using a new liquid gel pool method developed by the Piel group at University of Bonn (Hrvatin \& Piel, 2006 in press in J. Microbiol. Meth.). Employing these methods would greatly simplify our efforts, in terms of labor, time and consumables, in discovering single biocatalyst encoding genes of interest from symbiont's DNA.

\section{ACKNOWLEDGEMENTS}

We wish to thank Mr. Yogiara (Atmajaya Catholic University), Prof. J. Piel (University of Bonn, Germany), \& Dr. D. S. Retnoningrum (Institut Teknologi Bandung) for their helpful discussion and suggestion about the protocols developed and for sharing us some useful articles. Especially we thank Mrs. Y. N. Fawzya, Mr. Sugiyono, \& Mrs. D. S. Zilda (RCMFPPB-Research Agency for Marine and Fisheries) for giving us support, attention and advices during this research and Mr. D. Noviendri (RCMFPPB-Badan Riset Kelautan dan Perikanan) for critical discussion and input. We thank Dr. S. A. P. Dwiono (Indonesian Institute of Science) for helping us during sponge sampling in Lombok Island. We thank Erine G. Kawale \& Erlank Bagjavicenna, two bachelor students who joined us through a short internship, for their technical assistance during this research work.

Isolation and characterization of potential enzyme from marine microorganisms, F.Y. 2006, funded by Indonesia Government Through RAPBN.

\section{REFERENCES}

Bertrand, H., F. Poly, Van T. Van, N. Lombard, R. Nalin, T. M. Vogel, \& P. Simonet. 2005. High molecular weight DNA recovery from soils prerequisite for biotechnological metagenomic library construction. J. Microbiol. Meth. 62: 1-11. 
Bewley, C. A., N. D. Holland, \& D. J. Faulkner. 1996. Two classes of metabolites from Theonella swinhoei are localized in distinct populations of bacterial symbionts. Experientia. 52.

Faulkner, D. J. 2000. Marine pharmacology. Antonie van Leeuwenhoek. 77: 135-145.

Gudbjarnason, S. 1999. Bioactive marine natural products. Rit Fiskideildar. 16: 107-110.

Hrvatin, S. \& J. Piel. 2006. Rapid isolation of rare clones from highly complex DNA libraries by PCR analysis of liquid gel pools. In press in J. Microbiol. Meth.

Piel J., Hui D., Wen G., Butzke D., Platzer M., Fusetani N., \& Matsunaga S. 2004. Antitumor Polyketide Biosynthesis by an Uncultivated Bacterial Symbiont of the Marine Sponge, Theonella swinhoei. Proc. Natl. Acad. Sci. USA. 101(46): 16.222-16.227.
Sambrook, J. E. \& D. W. Russel. 2001. Molecular cloning: A laboratory manual. 2nd ed. Cold Spring Harbor Laboratory Press. Cold Spring Harbor. N. Y.

Schmidt, E. W., A. Y. Obraztsova, S. K. Davidson, D. J. Faulkner, M. G. Hygood. 2000. Identification of the antifungal peptide containing symbiont of the marine sponge, Theonella swinhoei as a novel äproteobacterium, "candidatus Enthoteonella palauensis". Marine Biology. 136: 969-977.

Thakur, N. L. \& W. E. G. Müller. 2004. Biotechnological potential of marine sponges. Current Science. 86 (11): 1.506-1.512.

Uria, A. R., R. Machielsen, B. E. Dutilh, M. A. Huynen, \& J. van der Oost. 2006. Alcohol dehydrogenases from marine hyperthermophilic microorganisms and their importance to the pharmaceutical industry. International Seminar and Workshop on Marine Biodiversity and their Potential for Developing Biopharmaceutical Industry in Indonesia. On the 17$18^{\text {th }}$ of May 2006 in Jakarta. 